\title{
Correction to: Genomic instability induced by radiation-mimicking chemicals is not associated with persistent mitochondrial degeneration
}

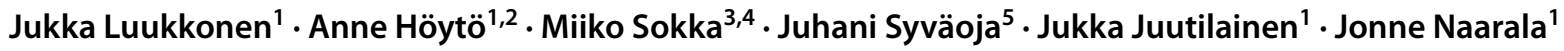

Published online: 2 December 2021

(c) The Author(s) 2021

\section{Correction to: Radiation and Environmental Biophysics https://doi.org/10.1007/s00411-021-00927-5}

Authors would like to correct the error in given name and family name which is incorrect in their publication. The correct version of author names updated.

The original article has been corrected.

Open Access This article is licensed under a Creative Commons Attribution 4.0 International License, which permits use, sharing, adaptation, distribution and reproduction in any medium or format, as long as you give appropriate credit to the original author(s) and the source, provide a link to the Creative Commons licence, and indicate if changes were made. The images or other third party material in this article are included in the article's Creative Commons licence, unless indicated otherwise in a credit line to the material. If material is not included in the article's Creative Commons licence and your intended use is not permitted by statutory regulation or exceeds the permitted use, you will need to obtain permission directly from the copyright holder. To view a copy of this licence, visit http://creativecommons.org/licenses/by/4.0/.
Publisher's Note Springer Nature remains neutral with regard to jurisdictional claims in published maps and institutional affiliations.

The original article can be found online at https://doi.org/10.1007/ s00411-021-00927-5.

Jukka Luukkonen

Jukka.Luukkonen@uef.fi

1 Department of Environmental and Biological Sciences, University of Eastern Finland, Yliopistonranta 1, P.O. Box 1627, 70211 Kuopio, Finland

2 STUK-Radiation and Nuclear Safety Authority, Helsinki, Finland

3 Department of Environmental and Biological Sciences, University of Eastern Finland, Joensuu, Finland

4 Department of Molecular Biology, Cell Biology and Biochemistry, Brown University, Providence, RI, USA

5 Institute of Biomedicine, University of Eastern Finland, Kuopio, Finland 